\title{
REPRESENTASI MATEMATIS SISWA DALAM MEMECAHKAN MASALAH MATEMATIKA KONTEKSTUAL DITINJAU DARI KEMAMPUAN MATEMATIKA
}

\author{
Wike Wijayanti \\ Pendidikan Matematika, FMIPA, Universitas Negeri Surabaya \\ email: wikewijayanti@mhs.unesa.ac.id \\ Siti Maghfirotun Amin \\ Pendidikan Matematika,FMIPA, Universitas Negeri Surabaya \\ e-mail: sitiamin@unesa.ac.id
}

\begin{abstract}
Abstrak
Representasi matematis merupakan penyajian ide matematis yang ditampilkan siswa untuk menemukan solusi masalah yang dihadapinya. Penelitian ini bertujuan untuk mendeskripsikan representasi matematis siswa dalam memecahkan masalah matematika kontekstual ditinjau dari kemampuan matematika. Jenis penelitian ini adalah deskriptif kualitatif. Metode pengumpulan data yang digunakan adalah tes kemampuan matematika, tes pemecahan masalah matematika kontekstual, dan wawancara. Penelitian ini dilakukan pada siswa Kelas VIII-F SMP Negeri 1 Ngawi tahun ajaran 2018/2019. Subjek penelitian adalah 3 siswa yang terdiri atas 1 siswa berkemampuan matematika tinggi, 1 siswa berkemampuan matematika sedang, dan 1 siswa berkemampuan matematika rendah. Peneliti melakukan wawancara berbasis tanya terhadap 3 siswa yang terpilih untuk menggali informasi lebih dalam sehingga mendapatkan data tentang representasi matematis siswa dalam memecahkan masalah matematika kontekstual. Hasil penelitian menunjukkan bahwa representasi yang dimunculkan siswa berkemampuan matematika tinggi dalam memahami masalah adalah representasi verbal, simbol, dan visual. Representasi yang dimunculkan siswa berkemampuan matematika tinggi dalam merencanakan penyelesaian adalah representasi simbol dan verbal. Representasi yang dimunculkan siswa berkemampuan matematika tinggi dalam melaksanakan rencana adalah representasi simbol dan verbal. Representasi siswa yang berkemampuan matematika tinggi dalam memeriksa kembali adalah representasi verbal. Representasi yang dimunculkan siswa berkemampuan matematika sedang dalam memahami masalah adalah representasi verbal dan simbol. Representasi yang dimunculkan siswa berkemampuan matematika sedang dalam merencanakan rencana adalah representasi verbal. Representasi yang dimunculkan siswa berkemampuan matematika sedang dalam melaksanakan rencana adalah representasi verbal dan simbol. Representasi siswa berkemampuan matematika sedang dalam memeriksa kembali adalah representasi verbal. Representasi yang dimunculkan siswa berkemampuan matematika rendah dalam memahami masalah adalah representasi simbol dan verbal. Representasi yang dimunculkan siswa berkemampuan matematika rendah dalam merencanakan penyelesaian adalah representasi simbol. Representasi yang dimunculkan siswa berkemampuan matematika rendah dalam melaksanakan rencana adalah representasi simbol. Representasi yang dimunculkan siswa berkemampuan matematika rendah dalam memeriksa kembali adalah representasi verbal.
\end{abstract}

Kata Kunci: Representasi Matematis, Pemecahan Masalah, Masalah Matematika Kontekstual, Kemampuan Matematika.

\begin{abstract}
Mathematical representation is the presentation of mathematical ideas displayed by students to find solutions to the problems. This study aims to describe the mathematical representation of students in solving contextual mathematical problems in terms of mathematical abilities. The research is qualitative descriptive. Data collection methods used were tests of mathematical abilities, tests of solving contextual mathematical problems, and interviews. This research was conducted on class VIII SMP Negeri 1-F Ngawi 2018/2019 academic year. The research subjects were 3 students consisting of 1 student with high mathematical abilities, 1 student with moderate mathematical abilities, and 1 student with low mathematical abilities. The researcher conducted a question-based interview on 3 selected students to dig deeper information so that they obtained data about students' mathematical representation in solving contextual mathematical problems. The results of the study showed that the representations raised by students with high mathematical abilities in understanding problems were verbal, symbolic, and visual representations. The representation that is raised by students with high mathematical abilities in planning solutions is symbolic and verbal representation. Representations raised by students with high mathematical abilities in carrying out plans are symbolic and verbal representations. Representation of students with high mathematical abilities in checking back is verbal representation. The representation that is raised by students with mathematical abilities while understanding problems is verbal representations and symbols. The representation that is raised by students with moderate mathematical abilities in planning a plan is verbal representation. Representations that are raised by students with mathematical abilities while carrying out plans are verbal representations and symbols. Representation of students with mathematical abilities who are currently checking again is verbal
\end{abstract}




\section{REPRESENTASI MATEMATIS SISWA ...}

representation. Representation that is raised by students with low mathematical abilities in understanding problems is symbolic and verbal representation. The representation that is raised by students with low mathematical abilities in planning solutions is symbolic representation. The representation that is raised by students with low mathematical abilities in implementing the plan is symbol representation. The representation raised by students with low mathematical abilities in checking back is verbal representation.

Keywords: Mathematical Representation, Problem Solving, Contextual Math Problems, Mathematical Abilities

\section{PENDAHULUAN}

Matematika adalah ilmu yang dibutuhkan diberbagai bidang, baik bidang matematika sendiri maupun bidang lain. Secara mendasar, matematika memiliki peranan penting dalam bidang pendidikan. Hal itu terlihat dari matematika yang diajarkan di setiap jenjang pendidikan, dari sekolah dasar hingga perguruan tinggi. Dalam memelajari matematika, siswa dituntut mencapai kompetensi yang telah ditetapkan oleh kurikulum.

Permendikbud Nomor 21 Tahun 2016 tentang Standar Isi disebutkan bahwa salah satu kompetensi yang harus dimiliki siswa adalah menggunakan simbol dalam pemodelan, megidentifikasi informasi, dan memiliki strategi yang paling efektif. Menggunakan simbol dalam pemodelan dapat disebut dengan representasi. Hwang, et al (2007:192) menyebutkan bahwa representasi merupakan proses pemodelan benda-benda konkrit dalam dunia nyata ke dalam konsep-konsep abstrak atau simbol-simbol. Representasi yang dimunculkan siswa merupakan penyajian ide matematika yang ditampilkan siswa untuk menemukan solusi dari masalah yang dihadapi. Penggunaan representasi memengaruhi pengetahuan yang akhirnya memengaruhi prestasi siswa. Oleh karena itu, penting untuk menyelidiki representasi matematis siswa dalam pembelajaran matematika.

Menurut Hwang et al (2007:192-193) representasi dibagi menjadi dua yaitu representasi eksternal dan representasi internal. Representasi internal adalah aktivitas mental untuk mendapatkan pengetahuan yang relevan. Representasi internal tidak dapat diamati secara kasat mata, dan apa yang ada didalam pikiran tidak diketahui. Namun, perwujudan pikiran akan terlihat dalam perkataan atau tulisan yang dinamakan dengan representasi eksternal.

Representasi selain berhubungan dengan ide matematika juga berhubungan dengan penyelesaian masalah matematika (Kartini, 2009). Dengan representasi dapat membantu siswa mengomunikasikan pemikirannya sehingga memudahkan dalam memahami konsep dan memecahkan masalah yang dihadapi. Masalah matematika yang dimunculkan sebaiknya masalah yang dekat dengan kehidupan sehari-hari (kontekstual) siswa. Anggo (2011) mendefinisikan masalah matematika kontekstual sebagai masalah yang berkaitan dengan konteks yang telah dikenal dalam kehidupan sehari-harinya.
Diperlukan tahap pemecahan masalah agar siswa dapat memecahkan masalah secara sistematis. Tahap pemecahan masalah yang digunakan adalah tahap pemecahan masalah Polya. Polya (1973) menyebutkan ada empat tahap pemecahan masalah yaitu : (1) Undersranding a plan, (2) Devising a plan, (3) Carrying out the plan, (4) Looking back.

Dalam belajar matematika, setiap siswa mempunyai kemampuan matematika yang berbeda-beda. Menurut Lestari (2010) kemampuan matematika dapat dikategorikan menjadi tiga yaitu siswa berkemampuan matematika tinggi, sedang, dan rendah. Rusminati (2014) menyatakan bahwa tingkat kemampuan matematika siswa memengaruhi representasi siwa dalam memecahkan masalah.

Menurut Aryanti, dkk (2013) sebagian besar siswa SMP masih lemah dalam menyatakan gagasannya melalui kata-kata atau teks tertulis, simbol, dan representasi dalam menyelesaikan masalah geometri. Persentase siswa yang menjawab benar untuk materi geometri Ujian Nasional Matematika SMP tahun 2017/2018 sebesar 41,40\%. Lebih lanjut, Setianingrum (2015) menyatakan bahwa siswa kesulitan untuk memahami materi bangun ruang sisi datar yang berdampak pada kemampuan representasi siswa.

Berdasarkan uraian diatas pertanyaan penelitian dalam penelitian ini adalah bagaimana representasi matenatis siswa berkemampuan matematika tinggi dalam memecahkan masalah matematika kontekstual, bagaimana representasi matematis siswa berkemampuan matematika sedang dalam memecahkan masalah matematika kontekstual, dan bagaimana representasi matematis siswa berkemampuan matematika rendah dalam memecahkan masalah matematika kontekstual.

Sedangkan tujuan penelitian ini adalah mendeskripsikan representasi matematis siswa berkemampuan matematika tinggi dalam memecahkan masalah matematika kontekstual, mendeskripsikan representasi matematis siswa berkemampuan matematika sedang dalam memecahkan masalah matematika kontekstual, dan mendeskripsikan representasi matematis siswa berkemampuan matematika rendah dalam memecahkan masalah matematika kontekstual.

\section{METODE}


Pendekatan penelitian ini adalah pendekatan kualitatif karena sesuai dengan tujuan dari penelitian ini yaitu mendeskripsikan representasi matematis siswa yang berkemampuan matematika tinggi, sedang, dan rendah dalam memecahkan masalah matematika kontekstual. Sedangkan untuk jenis penelitian ini adalah deskriptif.

Penelitian ini dilakukan di Kelas VIII-F SMP Negeri 1 Ngawi tahun ajaran 2018/2019. Subjek penelitian ini terdiri atas satu siswa berkemampuan matematika tinggi, satu siswa berkemampuan matematika sedang, dan satu siswa berkemampuan matematika rendah yang dipilih berdasarkan nilai Tes Kemampuan Matematika.

Instrumen yang digunakan dalam penelitian ini yaitu Tes Kemampuan Matematika (TKM), Tes Pemecahan Masalah Matematika Kontekstual (TPM), dan Pedoman Wawancara. Tes kemampuan matematika terdiri atas 5 soal uraian yang diadaptasi dari soal UN matematika dengan pemilihan materi yang sudah dipelajari siswa.Tes pemecahan masalah matematika kontekstual terdiri dari 1 soal yang berkaitan dengan kehidupan sehari-hari siswa guna menganalisis representasi matematis siswa. Siswa mengerjakan TPM menggunakan empat tahap pemecahan masalah Polya.

Instrumen yang digunakan dalam penelitian ini adalah Tes Kemampuan Matematika, Tes Pemecahan Masalah Matematika Kontekstual, Wawancara. Data yang diperoleh diperoleh dianalisis secara kualitatif dengan langkah Polya.

\section{HASIL DAN PEMBAHASAN}

Tes kemampuan matematika diikuti oleh 30 siswa di Kelas VIII-F. Dari hasil tes kemampuan matematika tersebut segera dikelompokkan kedalam tiga kelompok kemampuan matematika, yaitu kelompok kemampuan matematika tinggi, kemampuan matematika sedang, dan kemampuan matematika rendah. Selanjutnya, dipilih subjek penelitian dengan menggunakan patokan pemilihan subjek dan berdasarkan masukan dari guru mitra. Berikut merupakan subjek dalam penelitian ini

Tabel 1 Subjek Penelitian

\begin{tabular}{|l|l|l|l|}
\hline \multicolumn{1}{|c|}{ Nama } & \multicolumn{1}{|c|}{ Nilai } & \multicolumn{1}{c|}{ Kategori } & \multicolumn{1}{c|}{$\begin{array}{c}\text { Kode } \\
\text { Subjek }\end{array}$} \\
\hline MRI & 90 & Tinggi & MT \\
\hline PANLH & 82.5 & Sedang & MS \\
\hline IVWPA & 55 & Rendah & MR \\
\hline
\end{tabular}

Hasil dan pembahasan representasi matematis siswa dalam memecahkan masalah matematika kontekstual ditinjau dari kemampuan matematika yaitu sebagai berikut.
1. Representasi Matematis Siswa Kemampuan Matematika Tinggi dalam Memecahkan Masalah Matematika Kontekstual

Berikut penyelesaian yang dilakukan siswa berkemampuan matematika tinggi (MT) pada tahap memahami masalah.

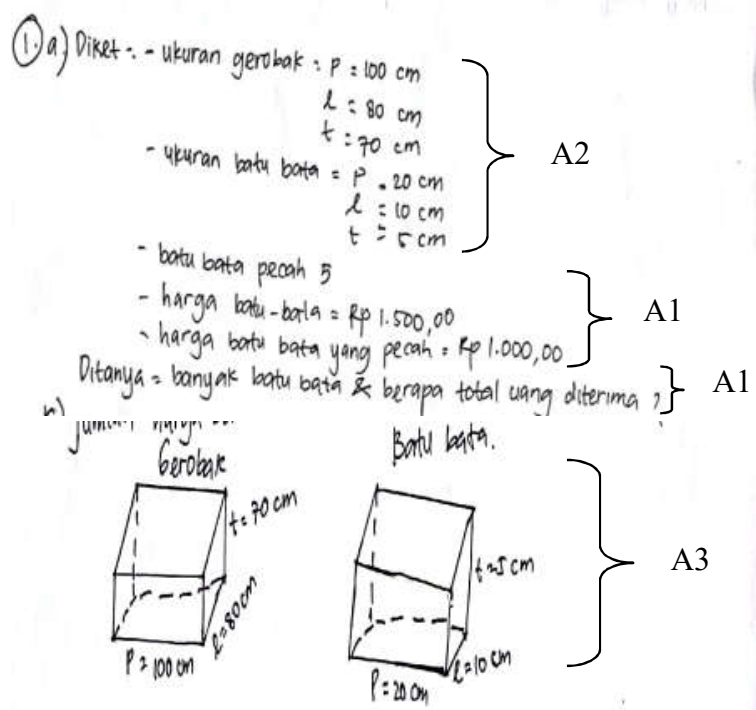

Gambar 1. 1 Hasil Penyelesaian MT dalam Memahami Masalah

MT menyajikan kembali informasi yang diketahui dalam soal yaitu ukuran gerobak dengan panjang $100 \mathrm{~cm}$, lebar $80 \mathrm{~cm}$, tinggi $70 \mathrm{~cm}$, ukuran batu bata dengan panjang $20 \mathrm{~cm}$, lebar $80 \mathrm{~cm}$, tinggi $70 \mathrm{~cm}$, batu bata pecah 5, harga batu bata Rp 1.500,00 dan harga batu bata yang pecah Rp1.000,00. MT memunculkan representasi verbal/teks tertulis, visual dan simbol sebagai pengganti dari "p" yang menyatakan panjang, "l" yang menyatakan lebar, dan " $\mathrm{l}$ " yang menyatakan tinggi. MT memunculkan representasi verbal berupa teks tertulis. MT menuliskan bahwa banyaknya batu bata yang pecah ada 5 , harga batu bata Rp $1.500,00$, dan harga batu bata yang pecah Rp 1.000,00. Representasi visual dapat ditunjukkan dengan jawaban MT berupa gambar gerobak dengan panjang $100 \mathrm{~cm}$, lebar 80 $\mathrm{cm}$, tinggi $70 \mathrm{~cm}$ dan gambar batu bata dengan panjang 20 $\mathrm{cm}$, lebar $10 \mathrm{~cm}$, tinggi $5 \mathrm{~cm}$. MT memerlukan waktu dua kali membaca soal untuk dapat memahami maksud soal.

MT dapat menuliskan dengan tepat apa yang ditanya menggunakan representasi verbal berupa teks tertulis. MT menuliskan bahwa yang ditanya dalam soal adalah banyak batu bata dan berapa total uang yang diterima.

Berikut penyelesaian yang dilakukan siswa berkemampuan matematika tinggi (MT) pada tahap merencanakan penyelesaian. 


\section{REPRESENTASI MATEMATIS SISWA ...}

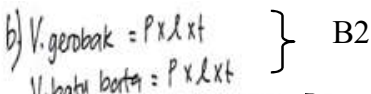

$$
\begin{aligned}
& \text { jumlah bate bata: } \left.=\frac{\text { V.gerobak }}{V \cdot \text { cababata }}\right\} \text { B1 }
\end{aligned}
$$

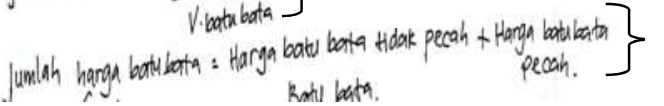

Gambar 1. 2 Hasil Penyelesaian MT dalam Merencanakan Penyelesaian

MT merencanakan penyelesaian dengan menggunakan representasi simbol dan verbal. MT menggunakan simbol sebagai pengganti "V" yang menyatakan volume, dan $p \times$ $l \times t$ sebagai rumus untuk mencari volume. MT memilih rencana penyelesaian seperti itu karena yang MT jumpai adalah rumus volume balok. MT dapat menjelaskan dengan baik rencana penyelesaian soal, mencari volume gerobak dan volume batu bata dengan rumus panjang kali lebar kali tinggi. Mencari jumlah batu bata yang termuat dalam gerobak dengan cara volume gerobak dibagi volume batu bata. Selanjutnya mencari jumlah harga batu bata yaitu harga batu bata tidak pecah ditambah harga batu bata pecah. Maksud harga batu bata tidak pecah adalah jumlah harga seluruh batu bata tidak pecah dan maksud harga batu bata pecah adalah jumlah harga seluruh batu bata pecah. MT tidak mempunyai cara lain untuk menyelesaikan soal tersebut. Representasi verbal ditunjukkan dengan jawaban MT yaitu jumlah batu bata yaitu volume gerobak dibagi volume batu bata dan jumlah harga batu bata = harga batu bata tidak pecah ditambah harga batu bata pecah.

Berikut penyelesaian yang dilakukan siswa berkemampuan matematika tinggi (MT) pada tahap melaksanakan rencana.

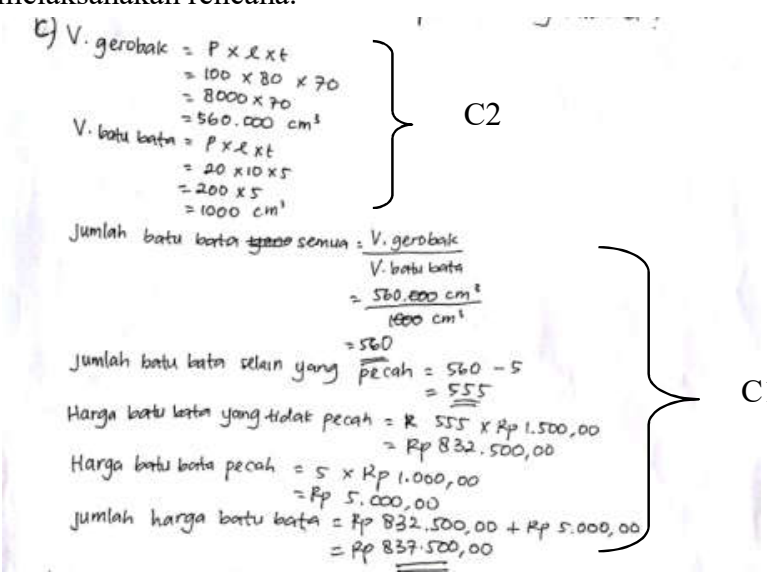

Gambar 1. 3 Hasil Penyelesaian MT dalam Melaksanakan Rencana

MT melaksanakan rencana penyelesaian dengan mencari terlabih dahulu volume gerobak dan volume batu bata dengan rumus volume balok. Mencari jumlah semua batu bata dengan cara volume gerobak dibagi volume batu bata. Lalu mencari jumlah batu bata selain yang pecah dengan cara jumlah semua batu bata dikurangi banyak batu bata yang pecah. Harga batu bata yang tidak pecah yaitu banyak batu bata yang tidak pecah dikali harga batu bata yang tidak pecah. Harga batu bata yang pecah yaitu banyaknya batu bata yang pecah dikali harga batu bata yang pecah. Lalu mencari jumlah harga batu bata dengan cara jumlah harga batu bata yang tidak pecah ditambah jumlah harga batu bata yang pecah. MT melaksanakan rencana dengan menggunakan representasi simbol dan verbal. MT menggunakan representasi simbol ditunjukkan dengan adanya penggunaan rumus volume balok dalam mencari volume gerobak dan volume batu bata. MT telah menyelesaikan masalah sesuai dengan rencana penyelesaian. MT juga telah melakukan perhitungan banyak batu bata dalam gerobak dan total uang yang diterima Pak Adi dengan tepat. Representasi verbal ditunjukkan dengan jawaban MT dalam mencari jumlah semua batu bata, jumlah batu bata selain yang pecah, harga batu bata yang tidak pecah, dan jumlah harga batu bata. MT melakukan langkah penyelesaian sesuai dengan rencana yang sudah dibuat.

Berikut penyelesaian yang dilakukan siswa berkemampuan matematika tinggi (MT) pada tahap memeriksa kembali.

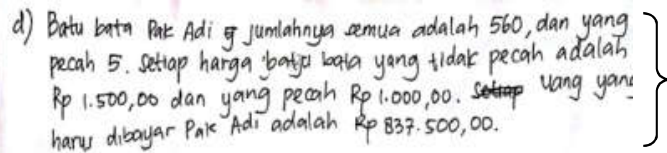

\section{Gambar 1. 4 Hasil Penyelesaian MT dalam Memeriksa Kembali}

MT menunjukkan jika jawabannya benar dengan cara rumus volume balok sehingga dapat digunakan untuk mencari banyak batu bata yang ada dalam gerobak, MT melakukan pengecekan kembali pada jawaban supaya kalo ada jawaban yang kurang tepat bisa di lengkapi lagi. MT melakukan pengecekan jawaban dengan cara menghitung ulang dan mengecek kembali rumus dan angka-angka. MT sudah yakin dengan jawabannya. MT menggunakan representasi verbal dalam memeriksa kembali jawaban, ditunjukkan dengan adanya penggunaan bahasa sendiri dalam penyimpulan jawaban akhir

2. Representasi Matematis Siswa Kemampuan Matematika Sedang dalam Memecahkan Masalah Matematika Kontekstual

Berikut penyelesaian yang dilakukan siswa berkemampuan matematika sedang (MS) pada tahap memahami masalah. 


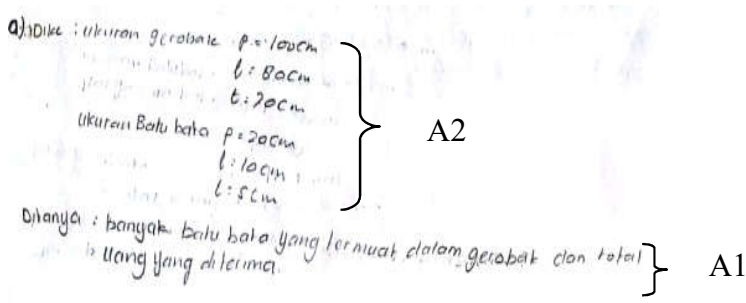

\section{Gambar 1. 5 Hasil Penyelesaian MS dalam Memahami Masalah}

MS menyajikan kembali informasi yang diketahui dalam masalah yaitu ukuran gerobak dengan panjang 100 $\mathrm{cm}$, lebar $80 \mathrm{~cm}$, tinggi $70 \mathrm{~cm}$, ukuran batu bata dengan panjang $20 \mathrm{~cm}$, lebar $80 \mathrm{~cm}$, tinggi $70 \mathrm{~cm}$. Namun, MS menuliskan apa yang diketahui kurang lengkap, tidak menuliskan harga batu bata, harga batu bata yang pecah, dan banyak batu bata yang pecah. MS menggunakan representasi verbal dan simbol sebagai pengganti dari " $p$ " yang menyatakan panjang, "l" yang menyatakan lebar, dan "t" yang menyatakan tinggi. MS memerlukan waktu dua kali membaca soal untuk dapat memahami soal.

MS dapat menuliskan dengan tepat apa yang ditanya menggunakan representasi verbal berupa teks tertulis. MS menuliskan bahwa yang ditanya dalam masalah adalah banyak batu bata dan berapa total uang yang diterima.

Berikut penyelesaian yang dilakukan siswa berkemampuan matematika sedang (MS) pada tahap merencanakan penyelesaian.

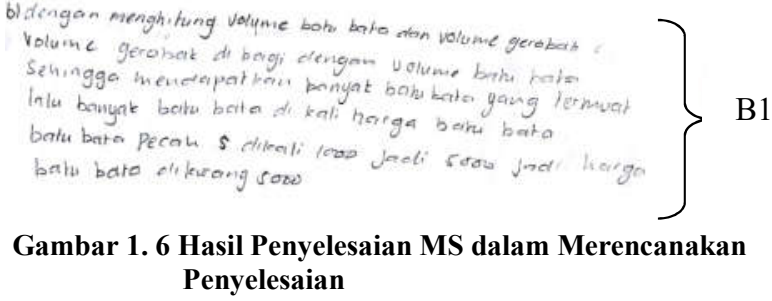

Gambar 1. 6 Hasil Penyelesaian MS dalam Merencanakan Penyelesaian

MS membuat perencanaan dengan menggunakan representasi verbal. Representasi verbal ditunjukkan dengan adanya penggunaan bahasa sendiri dalam membuat rencana penyelesaian. MS memilih rencana penyelesaian dengan menggunakan representasi verbal karena menurut MS lebih mudah. Harga batu bata dikurangi Rp 5.000,00 karena ada 5 batu bata yang pecah dan harga batu bata satuan Rp 1.000 sehingga 5 dikali Rp 1.000,00. MT dapat menjelaskan dengan baik rencana penyelesaian dari soal. Namun, MS menuliskan rencana penyelesaian kurang tepat yaitu jumlah harga batu bata adalah jumlah harga batu bata yang tidak pecah dikurangi jumlah harga batu bata pecah yang seharusnya jumlah harga batu bata yang tidak pecah ditambah dengan jumlah harga batu bata yang pecah. MS tidak mempunyai cara lain untuk menyelesaikan soal tersebut.
Berikut penyelesaian yang dilakukan siswa berkemampuan matematika sedang (MS) pada tahap melaksanakan rencana.

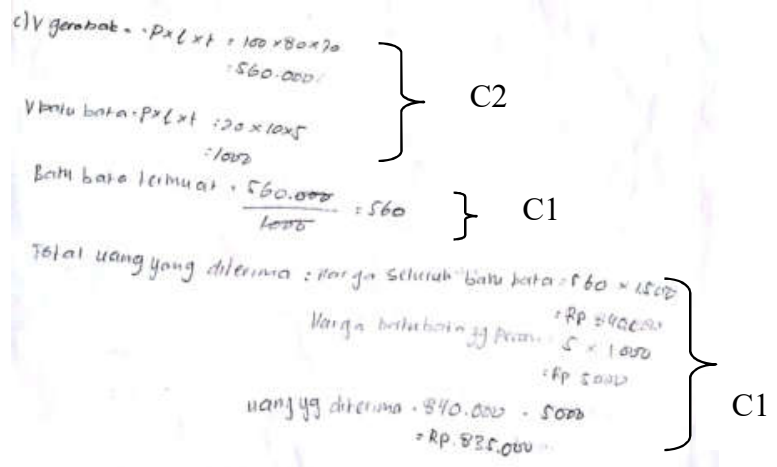

Gambar 1. 7 Hasil Penyelesaian MS dalam Melaksanakan Rencana

MS melaksanakan rencana penyelesaian dengan mencari terlabih dahulu volume batu bata dan volume gerobak dengan rumus volume balok. Mencari jumlah semua batu bata dengan cara volume gerobak dibagi volume batu bata. Lalu mencari total uang yang diterima Pak Adi yaitu harga seluruh batu bata dikurangi harga batu bata yang pecah. Harga seluruh batu bata dapat dicari dengan cara banyak batu bata dikali harga batu bata yang tidak pecah. Sedangkan harga sekuruh batu bata yang pecah dicari dengan cara banyak batu bata yang pecah dikali harga batu bata yang pecah. MT melaksanakan rencana dengan menggunakan representasi simbol dan verbal. MT menggunakan representasi simbol ditunjukkan dengan adanya penggunaan rumus volume balok dalam mencari volume gerobak dan volume batu bata. MS telah menyelesaikan masalah sesuai dengan rencana penyelesaian. Namun, MS menuliskan total uang yang diterima Pak Adi kurang tepat yaitu harga seluruh batu bata dikurangi harga batu bata yang pecah seharusnya harga seluruh batu bata yang tidak pecah ditambah harga seluruh batu bata yang pecah. Representasi verbal ditunjukkan dengan jawaban MS dalam mencari batu bata yang termuat dalam gerobak dan total uang yang diterima Pak Adi.

Berikut penyelesaian yang dilakukan siswa berkemampuan matematika sedang (MS) pada tahap memeriksa kembali.

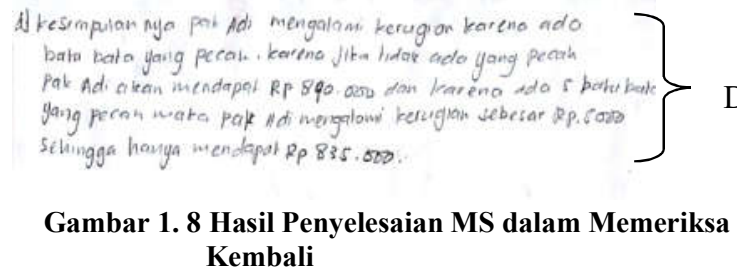

Gambar 1. 8 Hasil Penyelesaian MS dalam Memeriksa Kembali 


\section{REPRESENTASI MATEMATIS SISWA ...}

MS menunjukkan jika jawabannya benar dengan cara menunjukkan rumus yang digunakan dalam menyelesaikan soal yaitu rumus volume gerobak dan volume batu bata sehingga dapat digunakan untuk mencari banyak batu bata yang ada dalam gerobak, MS melakukan pengecekan kembali pada jawaban supaya lebih teliti dan benar. MS melakukan pengecekan jawaban dengan cara membaca kembali soal dan mengecek kembali semua jawaban. MS sudah yakin jika jawabannya benar. Namun, MS menuliskan jawaban kurang tepat yaitu uang yang diterima Pak Adi seharusnya Rp 837.500,00. MS menggunakan representasi verbal dalam memeriksa kembali jawaban, ditunjukkan dengan adanya penggunaan bahasa sendiri dalam penyimpulan jawaban akhir.

\section{Representasi Matematis Siswa Kemampuan Matematika Rendah dalam Memecahkan Masalah Matematika Kontekstual}

Berikut penyelesaian yang dilakukan siswa berkemampuan matematika rendah (MR) pada tahap memahami masalah.

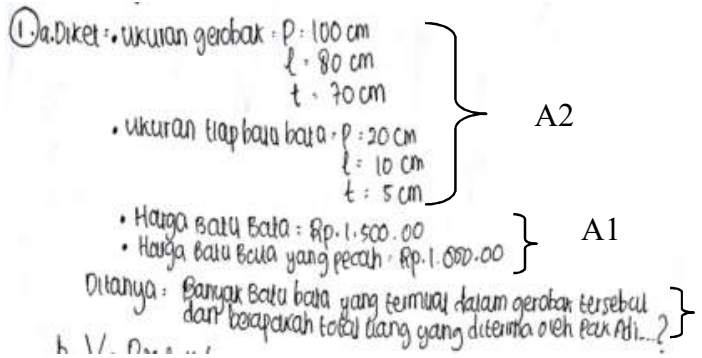

Gambar 1. 9 Hasil Penyelesaiann MR dalam Memahami Masalah

MR menyajikan kembali informasi yang diketahui dalam masalah yaitu ukuran gerobak dengan panjang 100 $\mathrm{cm}$, lebar $80 \mathrm{~cm}$, tinggi $70 \mathrm{~cm}$, ukuran batu bata dengan panjang $20 \mathrm{~cm}$, lebar $80 \mathrm{~cm}$, tinggi $70 \mathrm{~cm}$, harga batu bata Rp 1.500,00, harga batu bata yang pecah Rp 1.000,00. Namun, MR menuliskan apa yang diketahui kurang lengkap, tidak menuliskan banyak batu bata yang pecah. MR menggunakan representasi verbal atau teks tertulis dan simbol sebagai pengganti dari "p" yang menyatakan panjang, "l" yang menyatakan lebar, dan "t" yang menyatakan tinggi. Representasi verbal ditunjukkan dengan jawaban MR yaitu harga batu bata Rp 1.500,00 dan harga batu bata yang pecah Rp 1.000,00.

MR dapat menuliskan dengan tepat apa yang ditanya menggunakan representasi verbal berupa teks tertulis. MR menuliskan bahwa yang ditanya dalam masalah adalah banyak batu bata yang termuat dalam gerobak dan berapa total uang yang diterima oleh Pak Adi.

Berikut penyelesaian yang dilakukan siswa berkemampuan matematika rendah (MR) pada tahap merencanakan penyelesaian.

\section{b. $V=P \times l \times t\}$ B2}

Gambar 1. 10 Hasil Penyelesaian MR dalam Merencanakan Penyelesaian

MR membuat perencanaan dengan menggunakan representasi simbol sebagai pengganti "V" yang menyatakan volume. MS membuat rencana dengan membaca dan memahaminya terlebih dahulu (MR-09), rencana yang dilakukan MR yaitu mencari volume dengan rumus volume balok. Namun, MR menuliskan rencana penyelesaian kurang lengkap, MR hanya menuliskan rencana untuk mencari volume tidak menuliskan rencana untuk mencari jumlah harga batu bata yang tidak pecah, yang pecah dan banyak uang yang diterima tetapi pada saat proses wawancara MR dapat menjawab pertanyaan dari peneliti ketika peneliti bertanya total uang yang diterima oleh Pak Adi meskipun jawaban MR kurang tepat. MR tidak mempunyai cara lain untuk menyelesaikan soal tersebut.

Berikut penyelesaian yang dilakukan siswa berkemampuan matematika rendah (MR) pada tahap melaksanakan rencana.

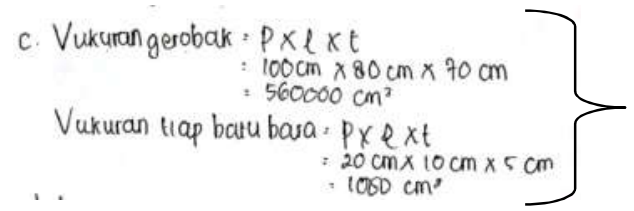

Gambar 1. 11 Hasil Penyelesaian MR dalam Melaksanakan Rencana

MR melaksanakan rencana penyelesaian dengan mencari terlabih dahulu volume batu bata dan volume gerobak dengan rumus volume balok. MR menggunakan representasi simbol ditunjukkan dengan adanya penggunaan rumus volume balok dalam mencari volume gerobak dan volume batu bata. MR telah menyelesaikan masalah sesuai dengan rencana penyelesaian. Namun, MS menuliskan penyelesaian kurang lengkap, tidak menuliskan penyelesaian dari pertanyaan total uang yang diterima Pak Adi.

Berikut penyelesaian yang dilakukan siswa berkemampuan matematika rendah (MR) pada tahap memeriksa kembali.

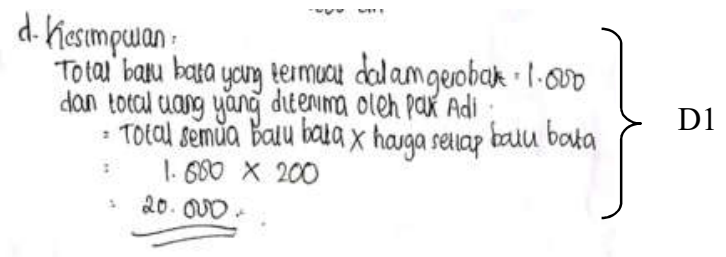

Gambar 1. 12 Hasil Penyelesaian MR dalam Memeriksa Kembali 
MR menunjukkan jika jawabannya benar dengan cara MR menggunakan rumus dan angka yang dimasukkan pada rumus sesuai dengan ukuran gerobak, MR melakukan pengecekan kembali pada jawaban supaya lebih mengetahui bahwa jawaban tersebut memang tepat. MR melakukan pengecekan jawaban dengan cara mengecek kembali semua jawaban. MS sudah yakin jika jawabannya benar. Namun, MS menuliskan jawaban kurang tepat yaitu uang yang diterima Pak Adi seharusnya Rp 837.500,00. MS menggunakan representasi verbal dalam memeriksa kembali jawaban, ditunjukkan dengan adanya penggunaan bahasa sendiri dalam penyimpulan jawaban akhir.

\section{PENUTUP}

\section{Simpulan}

Berdasarkan hasil dan pembahasan, diperoleh simpulan representasi natematis siswa dalam memecahkan masalah matematika kontekstual ditinjau dari kemampuan matematika sebagai berikut.

1. Representasi Matematis Siswa Kemampuan Matematika Tinggi dalam Memecahkan Masalah Matematika Kontekstual

\section{Memahami Masalah}

Dalam memahami masalah, epresentasi yang dimunculkan siswa adalah representasi simbol, verbal, dan visual. Siswa menyajikan kembali informasi dengan tepat dan lengkap. Siswa berkempuan matematika tinggi dapat menuliskan apa yang ditanya dengan tepat menggunakan representasi verbal.

\section{Merencanakan Penyelesaian}

Dalam merencanakan penyelesaian, representasi yang dimunculkan siswa adalah representasi simbol dan verbal. Siswa menuliskan rencana penyelesaian dengan jelas dan benar.

\section{Melaksanakan Rencana}

Dalam melaksanakan rencana, representasi yang dimunculkan siswa adalah representasi simbol dan verbal. Siswa telah melaksanakan rencana penyelesaian sesuai dengan rencana yang sudah dibuat. Siswa juga telah melakukan perhitungan dengan benar.

\section{Memeriksa Kembali}

Dalam memeriksa kembali, representasi yang dimunculkan siswa adalah representasi verbal. Siswa melakukan pengecekan kembali jawaban dengan menghitung ulang dan mengecek kembali rumus dan angka-angkanya supaya kalo ada yang kurang lengkap bisa dilengkapi lagi.

2. Representasi Matematis Siswa Kemampuan Matematika Sedang dalam Memecahkan Masalah Matematika Kontekstual

Memahami Masalah

Dalam memahami masalah, representasi yang dimunculkan siswa adalah representasi verbal dan simbol.
Siswa menyajikan informasi kurang lengkap. Siswa menyajikan kembali apa yang tanya menggunakan representasi verbal.

\section{Merencanakan Penyelesaian}

Dalam merencanakan penyelesaian, representasi yang dimunculkan siswa adalah representasi verbal berupa teks tertulis. Namun, siswa menuliskan rencana penyelesaian kurang tepat.

\section{Melaksanakan Rencana}

Dalam merencanakan penyelesaian, representasi yang dimunculkan siswa adalah representasi verbal dan simbol. Siswa berkemampuan matematika sedang telah menyelesaikan masalah sesuai dengan rencana penyelesaian dan telah melakukan perhitungan. Namun rencana yang telah dibuat kurang tepat.

\section{Memeriksa Kembali}

Dalam memeriksa kembali, representasi yang dimunculkan siswa adalah representasi verbal. Siswa menggunakan representasi verbal dalam memeriksa kembali jawaban. Namun masih terdapat kesalahan sehingga hasil jawaban siswa kurang tepat.

3. Representasi Matematis Siswa Kemampuan Matematika Rendah dalam Memecahkan Masalah Matematika Kontekstual

Memahami Masalah

Dalam memahami masalah, representasi yang dimunculkan siswa adalah representasi simbol dan verbal. Namun, siswa tidak menuliskan banyaknya batu bata yang pecah. Siswa dapat menuliskan dengan tepat apa yang ditanya menggunakan representasi verbal.

\section{Merencanakan Penyelesaian}

Dalam merencanakan penyelesaian, representasi yang dimunculkan siswa adalah representasi simbol. Namun, siswa menuliskan rencana penyelesaian kurang lengkap

\section{Melaksanakan Rencana}

Dalam melaksanakan rencana, representasi yang dimunculkan siswa adalah representasi simbol. Siswa berkemampuan matematika rendah telah menyelesaikan masalah sesuai dengan rencana penyelesaian dan telah melakukan perhitungan. Namun rencana yang telah dibuat kurang lengkap.

\section{Memeriksa Kembali}

Pada tahap memeriksa kembali, representasi yang dimunculkan siswa adalah representasi verbal, namun masih terdapat kesalahan sehingga jawaban kurang tepat.

\section{Saran}

Berdasarkan hasil penelitian yang telah dilakukan, peneliti memberikan saran yaitu bagi peneliti lain diharapkan dapat menggali informasi lebih banyak lagi bagaimana cara siswa mengecek setiap tahapan pemecahan masalah dan 


\section{REPRESENTASI MATEMATIS SISWA ...}

bagaimana cara siswa melakukan perhitungan ulang. Sehingga dapat diketahui representasi matemmatis siswa pada tahap memeriksa kembali.

\section{DAFTAR PUSTAKA}

Anggo, M. 2011. "Pemecahan Masalah Matematika Kontekstual untuk Meningkatkan Kemampuan Metakognisi Siswa”. Jurnal Edumatica. Vol 1(2): hal. $35-42$

Aryanti, D. Zubaidah dan Nursanggi, A. 2013. "Kemampuan Representasi Matematis Menurut Tingkat Kemampuan Siswa pada Materi Segiempat di SMP”. Jurnal Pendidikan dan Pembelajaran, (Online), Vol. 2(1), (http://jurnal.untan.ac.id/index.php/jpdpb/article/vie w/812).

Hwang, W.Y., Chen, N.S., Dung, J.J., \& Yang, Y.L. 2007. "Multiple Representation Skills and Creativity Effects on mathematical Problem Solving using a Multimedia Whiteboard System". Educational Technology \& Society. Vol. 10(2): hal. 191-212.
Kartini. 2009. "Peranan Representasi dalam Pembelajaran Matematika". Seminar Nasional FMIPA Yogyakarta, 5 Desember 2009.

Lestari, S.N.D. 2010. Profil Pemecahan Masalah Matematika Open-Ended Siswa Kelas V Sekolah Dasar ditinjau dari Perbedaan Gender dan Kemampuan Matematika. Tesis tidak diterbitkan. Surabaya. PPs Universitas Negeri Surabaya.

Permendikbud. 2016. Permendikbud No. 21 tentang Standar Isi Pendidikan Dasar dan Menengah. Jakarta: Kementerian Pendidikan dan Kebudayaan.

Polya, G. (1973). How to Solve It: A New Aspect of Mathematical Method. Second Edition. New Jersey: Princeton University Press.

Rusminati, S.H. 2014. Representasi Eksternal Siswa dalam Pemecahan Masalah Desimal Ditinjau dari Kemampuan Matematika. Tesis tidak diterbitkan. Surabaya: PPs Universitas Negeri Surabaya.

Setianingrum, E.P. 2015. Analisis Kemampuan Representasi Matematis Siswa pada Whole Brain Teaching dengan Pendekatan Realistik. Tesis. Semarang: Universitas Negeri Semarang. 